\title{
BRD2 wt Allele
}

National Cancer Institute

\section{Source}

National Cancer Institute. BRD2 wt Allele. NCI Thesaurus. Code C52492.

Human BRD2 wild-type allele is located in the vicinity of $6 \mathrm{p} 21.3$ and is approximately 12 $\mathrm{kb}$ in length. This allele, which encodes bromodomain-containing 2 protein, plays a role in the modulation of signal transduction. This gene is expressed aberrantly in some leukemias. 